\title{
Analisis Motif Kerajinan Anyaman Bambu Di Desa Mandalagiri Kecamatan Leuwisari Kabupaten Tasikmalaya
}

\author{
Tuti Alawiyah, Wan Ridwan Husen, Asti Tri Lestari \\ Universitas Muhammadiyah Tasikmalaya \\ JI.Tamansari No. KM 2.5 Mulyasari Kec. Tamansari Tasikmalaya Jawa Barat Indonesia \\ Email: tutia1521@gmail.com
}

\begin{abstract}
ABSTRAK
Desa Mandalagiri Kecamatan Leuwisari Kabupaten Tasikmalaya memiliki potensi alam bambu yang melimpah untuk dijadikan bahan baku anyaman bambu, maka dari itu pengranjin anyaman bambu hampir tersebar diseluruh Desa Mandalagiri. Didaerah tersebut kerajinan anyaman bambu masih di lestarikan bahkan dijadikan sebagai usaha untuk mencari nafkah. Penelitian ini bertujuan untuk menganalisis motif dan mengetahui teknik pembuatan motif kerajinan anyaman di desa Mandalagiri Kecamatan Leuwisari Kabupaten Tasikmalaya. Metode yang digunakan dalam penelitian ini metode kualitatif dengan pendekatan deskriptif. Motif anyaman bambu yang tedapat di Desa Mandalagiri sangat beragam tetapi hanya dua motif saja yang sering digunakan yaitu motif anyaman sasag dan motif anyaman kepang, teknik pembuatan anyaman bambu di Desa Mandalagiri tidak menggunakan mesin bubut melainkan menggunakan tangan manual. Teknik pengumpulan data melalui, observasi, wawancara, dokumentasi dan studi literatur.
\end{abstract}

Kata Kunci : Anyaman bambu, Motif, Teknik

\section{ABSTRACT}

Mandalagiri Village, Leuwisari District, Tasikmalaya Regency has abundant natural potential of bamboo to be used as raw material for woven bamboo, therefore bamboo woven craftsmen are almost scattered throughout Mandalagiri Village. In the area, woven bamboo crafts are still preserved and even used as an effort to make a living. This study aims to analyze the motifs and determine the technique of making woven craft motifs in Mandalagiri Village, Leuwisari District, Tasikmalaya Regency. The method used in this study is a qualitative method with a descriptive approach. The woven bamboo motifs found in Mandalagiri Village are very diverse, but only two motifs are often used, namely the woven sasag motif and the woven braid motif, the technique of making woven bamboo in Mandalagiri Village does not use a lathe but uses manual hands. Data collection techniques through observation, interviews, documentation and literature studies.

Keywords: Woven bamboo, Motif, Technique

\section{A. Pendahuluan}

Indonesia merupakan negara yang memiliki ribuan pulau dari Sabang sampai Merauke, serta memiliki beraneka ragam budaya dengan corak dan keunikannya yang khas pada tiaptiap daerah. Koentjaraningrat (1974:164) mengatakan, budaya pada tiap daerah harus memiliki tujuh unsur budaya seperti bahasa, sistem pengetahuan, organisasi sosial, sistem peralatan hidup, teknologi, sistem mata pencaharian, sistem religi dan juga kesenian.

Perkembangan kesenian di Indonesia menunjukan grafik yang cukup pesat. Hal ini dapat dilihat dari segi kualitas yang diproduksi dalam seni kriya, contohnya kerajinan anyaman. Kerajinan anyaman merupakan kerajinan tradisional yang masih ditekuni sampai saat ini. Kerajinan anyaman ini dapat dijadikan tolak ukur perkembangan seni kriya baik kriya sebagai seni maupun seni kerajinan pemenuh kebutuhan pasar. Anyaman di Indonesia telah lama ada dan terus berkembang sampai sekarang. Perkembangan itu meliputi pemanfaatan bahan, bentuk, dan motif yang bervariasi sehingga tidak kelihatan monoton.

Menganyam adalah suatu kegiatan keterampilan masyarakat dalam pembuatan barang dengan cara atau teknik susup menyusup, tindih menindih 
dan saling lipat melipat antara lungsung dan pakan sehingga saling menguatkan antara satu dengan yang lainnya, (Rosna, 2009: 9).

Motif dari kerajinan anyaman tiap daerah berbeda-beda nama dan maknanya. Daerah yang di nilai memiliki potensi tinggi dalam sentra anyaman salah satunya terletak di Priangan Timur Jawa Barat yaitu Tasikmalaya. Dari banyaknya sentra kerajinan bambu yang ada di Tasikmalaya, peneliti mengambil sentra kerajinan bambu yang berada di Desa Mandalagiri kecamatan Leuwisari kabupaten Tasikmalaya sebagai bahan untuk dijadikan judul penelitian. Desa Mandalagiri memiliki potensi besar dalam bidang kerajinan terutama berbahan dasar bambu, karena di desa tersebut sangatlah mudah ditemukan pohon bambu sebagai bahan baku anyaman, hal itu membuat pengrajin anyaman bambu tersebar hampir di seluruh Desa Mandalagiri.

Pertimbangan penulis melakukan penelitian ini adalah salah satu upaya mendokumentasikan untuk lebih memperkenalkan motif kerajinan anyaman bambu yang ada di daerah tersebut, karena menurut penulis kualitas kerajinan yang ada disana cukup baik dan sangat berpotensi, namun daerah itu belum cukup dikenal oleh masyarakat.

\section{B. Metode Penelitian}

Metode yang digunakan dalam penelitian ini adalah metode kualitatif dengan pendekatan deskriptif. Metode Kualitatif ini dirasa paling tepat dan relevan untuk digunakan dalam penelitian ini, terutama untuk menggali semua data hasil penelitian dan memecahkan beberapa permasalahan yang ingin dikaji agar dapat dipaparkan dan mempermudah dalam memberikan gambaran mengenai analisis motif kerajinan anyaman bambu di Desa Mandalagiri Kecamatan Leuwisari Kabupaten Tasikmalaya secara faktual dan naturalistik.

Penelitian ini menggunakan pendekatan deskriptif dengan tujuan untuk mendeskripsikan objek penelitian atupun hasil penelitian dikarenakan judul yang peneliti angkat lebih mengarah pada pendeskripsian sesuatu, jadi pendekatan deskriptif ini yang sesuai dengan judul peneliti dimana dalam penelitian ini mencoba mendeskripsikan, menguraikan, dan menggambarkan tentang analisis motif kerajinan anyaman bambu di Desa Mandalagiri Kecamatan Leuwisari Kabupaten Tasikmalaya.

Teknik pengumpulan data yang digunakan dalam penelitian ini adalah teknik observasi, teknik wawancara, teknik dokumen dan studi pustaka. observasi dalam melaksanakan penelitian ini yaitu dengan mengamati langsung ke lapangan untuk melihat objek yang akan diteliti. Teknik wawancara yang digunakan dalam penelitian ini adalah wawancara semi terstruktur di mana akan dilakukan kepada pemilik sentra anyaman di Desa Mandalagiri. Tujuan dari penggunaan wawancara semi terstruktur adalah untuk menemukan permasalahan secara lebih terbuka. Teknik dokumentasi dilakukan untuk mencari bukti-bukti yang dapat disimpan seperti rekaman, video, poto-poto sehingga menghindari kemungkinan hilang data-data yang telah diberikan oleh narasumber. Studi pustaka dilakukan dengan membaca teori-teori dari buku atau sumber lainnya.
C. Hasil Penelitian Dan Pembahasan
1. Sejarah dan Perkembangan Anyaman Bambu di Desa Mandalagiri 
Sejarah anyaman bambu di Desa Mandalagiri dimulai sejak masa kolonial Belanda sekitar tahun 1940an, dimana pada waktu itu banyak penduduk setempat yang membuat tampir, ayakan dan boboko ( bakul nasi ). Boboko yang dibuat masyarakat tersebut biasanya berbentuk bundar cembung, bagian bawahnya berbentuk segi empat yang juga terbuat dari bambu sebagai kaki.

Pada tahun 1985, seorang pengrajin bernama Oman membuat barang lain yang dikembangkan dari kerajinan boboko, boboko yang berbentuk bundar cembung dimodifikasi menjadi bebeapa barang dan memiliki berbagai jenis kegunaan antara lain, kap lampu, toples kue, vas bunga, dan lain-lain. Waktu itu Bapa Oman belum punya satupun karyawan beliau hanya mengandalkan keluarga untuk membantu usahanya. Tradisi menganyam secara turun temurun dikembangkan oleh generasi berikutnya hingga beberapa pengrajin berhasil mengembangkan usahanya dibidang pemasaran dan mendirikan badan usaha sendiri.

Pada perkembangnya, sekitar tahun zoooan usaha kerajinan anyaman bambu di Desa Mandalagiri mulai hidup dan berkembang hingga sekarang, bahkan sekarang berhasil menjadi produsen yang menghasilkan produk berdasarkan pesanan konsumen untuk pasar luar daerah.

2. Nilai Filosofis dan Makna Simbolis

\section{Anyaman Bambu}

Dalam pembahasan mengenai analisis khususnya analisa tentang nilai filosofis dan makna simbolik pada motif anyaman bambu, maka penelitit lebih mengkhususkan pembahasan mengenai nilai filosofis dan makna simbolis terhadap analisa umum tentang anyaman bambu Desa Mandalagiri.

Nilai filosifis anyaman bambu terdapat pada ayakan, ayakan merupakan alat yang terbuat dari anyaman bilah bambu halus berbentuk bulat, biasanya digunakan untuk menangkap benih ikan atau untuk menampung ikan sementara.

Kakek Odo (75) menuturkan pada zaman dahulu ketika bayi dilahirkan untuk melepas ari-arinya itu menggunakan hinis awi (sembilu dari bambu) kemudian ari-arinya dicuci lalu dimasukan kedalam bambu kemudian ditutup menggunakan batok (tempurung kelapa) yang sudah dilubangi, lalu atasnya memakai selubung dari bambu yang berfungsi untuk menyiram ari-ari tersebut selama 40 hari. Setelah ari-arinya diambil bayi tersebut disimpan didalam ayakan kemudian lingkaran sisi ayakan ditimrag menggunakan dua halu ( alat tumbuk terbuat dari kayu ) secara bersamaan, sisi kiri dan kanan serta atas dan bawah sambil menyebutkan hari, dimulai dari hari kelahiran bayi tersebut sampai hari lahirnya lagi, misalkan bayi tersebut lahir pada hari Sabtu " Sabtu, Minggu, Senin, Selasa, Rabu, Kamis, Jumat, Sabtu ). Bapak Oman (61) menjelaskan kembali bahwa anyaman Mandalagiri terbuat dari bahan alam yaitu bambu hal itu lantaran wilayah dilereng gunung Galunggung ini banyak ditumbuhi oleh pohon bambu. Menandakan bahwa Suku Sunda Mandalagiri lebih dekat dengan alam. Kakek Odo (75) menjelaskan lebih jauh, proses pembuatan atau proses menganyam ini sangat lama, ini melambangkan kesabaran seseorang dalam menyelesaikan sesuatu yang dibuat.

3. Proses Pembuatan Kerajinan Anyaman Bambu

a. Pemilihan Bahan Bambu

Bambu yang digunakan pada anyaman Desa Mandalagiri merupakan bambu yang berkualitas baik dan tidak mudah rusak apabila mengalami 
penyusutan yaitu bambu apus (awi tali). Menurut Pak Oman (61) umur bambu yang baik untuk anyaman biasanya 8 bulan-1 tahun.

\section{b. Pemotongan}

Setelah bambu diambil kemudian bambu dipotong dengan menggunakan golok atau gergaji. Setelah dipotong bambu akan di potong lagi menjadi bagian-bagian yang lebih pendek, ukuran yang biasa dipakai yaitu dipotong perbuku bambu.

\section{c. Pembelahan}

Setelah proses pemotongan bambu selanjutnya yaitu proses pembelahan bambu. Proses pembelahan bambu ini merupakan proses pembagian bambu menjadi bagian-bagian yang lebih kecil. pembelahan bambu ini dilakukan menggunakan alat blakas atau pisau dengan ukuran besar (golok). Bambu bisa dibelah menjadi dua ukuran yang sama.

\section{d. Pembersihan}

Selanjutnya proses pembersihan, bambu harus dibersihkan dari cabangcabang dan kulit bamu. Selain menghilangkan cabang dan kulit bambu, bambu juga harus dibersihkan dari merang bambu yang berwarna hitam yang menmpel pada bambu.

\section{e. Malpal atau Pemisahan Kulit Bambu} Malpal merupakan proses pemisahan antara kulit luar bambu dengan isi bambu. Selanjutnya bambu yang sudah dibelah menjadi beberapa bagian akan di bagi lagi menjadi bagian yang lebih tipis, biasanya dikenal dengan proses penyisitan (ngaraut).

\section{f. Pengeringan}

Proses pengeringan ini dilakukan dengan cara menyimpan bahan dibawah teriknya matahari (dijemur langsung) tidak perlu menggunakan alat pengering.

\section{g. Penganyaman Bambu}

Dalam proses penganyaman, bambu akan terbentuk sebuah motif dari anyaman itu sendiri. Motif itu timbul karena perbedaan letak bambu yang dianyam. Proses menganyam bambu ini tidak hanya dilakukan disatu tempat tetapi dibeberapa rumah disekitar Desa Mandalagiri.

\section{h. Ngabingkai}

Pada proses ini merupakan

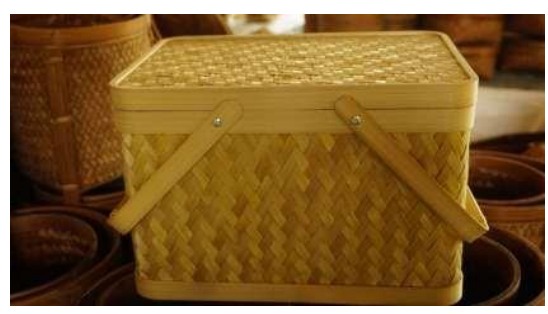

proses pemberian bingkai kerajinan menggunakan lem. Setelah anyaman bambu sudah selesai dianyam, maka selanjutnya sisa dari bambu yang tidak teranyam akan digunting dan diberi bingkai bambu.

\section{i. Pewarnaan}

Menurut Bapa Oleh (35) "alat yang digunakan untuk mengecat adalah mesin semprot, pewarnaan dilakukan dengan teknik semprot, yaitu mewarnai dengan cara menyemprot produk anyaman bambu dengan jarak kurang lebih 25-30 cm".

\section{j. Produk yang dihasilkan}

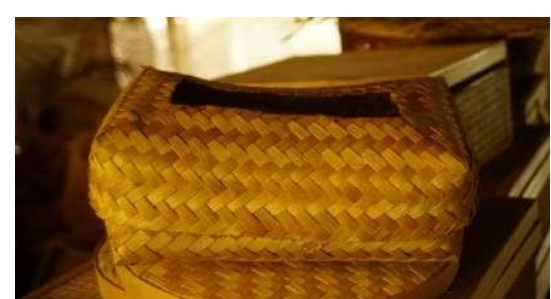

Kerajinan anyaman bambu di Desa Mandalagiri menghasilkan beberapa produk dari 2 motif, yaitu dari motif anyaman sasag dan motif anyaman kepang. Menurut Bapa Oman (61) "ada banyak produk yang dihasilkan anyaman bambu Desa Mandalagiri ini, produk yang diproduksi disini sesuai permintaan konsumen dan tidak ketinggalan trend 
saat ini tetapi tidak melupakan ciri khas budaya". Jenis-jenis produk yang dihasilkan terbagi ke dalam enam jenis, ke enam jenis tersebut dihasilkan dari 2 jenis motif dengan bentuk yang berbedabeda. Produk yang dihasilkan dari 2 motif tersebut antara lain :

\section{1) Keranjang piknik}

Produk keranjang piknik ini memiliki ukuran panjang $30 \mathrm{~cm}$, lebar 20 $\mathrm{cm}$ dan tinggi $20 \mathrm{~cm}$. Anyaman dalam produk ini menggunakan motif kepang dengan tambahan bambu untuk jinjinganya, warna yang digunakan dalam produk ini yaitu warna asli dari bambu. Nilai alami yang dihasilkan oleh keranjang piknik tetap terlihat, per pcs keranjang piknik ini dibandrol dengan harga Rp.100.00.

Gambar 1. Keranjang piknik

Sumber : Dokumentasi pribadi

\section{2) Kotak tisu simple}

Produk kotak tisu ini memiliki ukuran panjang $25 \mathrm{~cm}$ dan tinggi $10 \mathrm{~cm}$, motif anyaman yang digunakan pada produk ini merupakan motif anyaman kepang.

Gambar 2. Kotak tisu simple

Sumber : Dokumentasi pribadi

\section{3) Keranjang buah}

Motif anyaman yang digunakan pada produk ini menggunakan motif anyaman sasag dengan diameter $30 \mathrm{~cm}$ dan tinggi $10 \mathrm{~cm}$. Warna yang digunakan yaitu warna asli bambu serta diberi tambahan warna coklat tua sebagai pemanis.

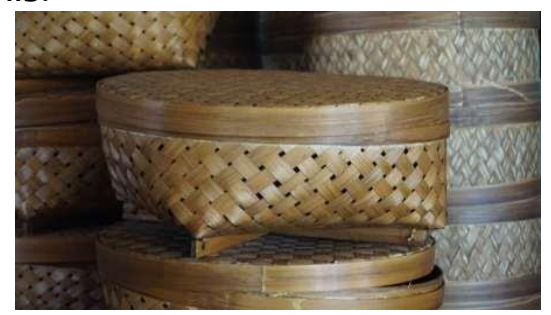

Gambar 3. Keranjang buah

Sumber : Dokumentasi pribadi

\section{4) Rantang}

Dinamakan rantang karena bentuknya bersusun dan memiliki tutup, sama dengan jenis rantang pada umumnya. Menurut Bapa Oman (61) “ rantang ini berfungsi sebagai wadah/tempat tupperware yang sudah diisi makanan, atasnya dilengkapi tangkai sebagai pengait agar mudah dibawa kemana-mana".

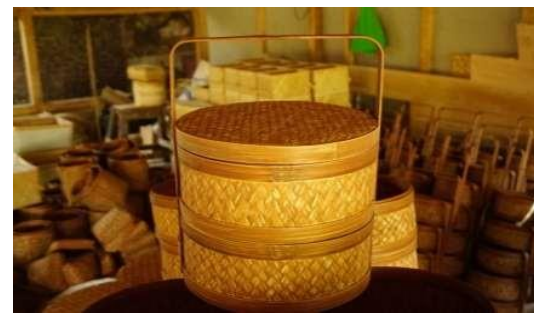

Gambar 4 . Rantang

Sumber : Dokumentasi pribadi

\section{5) Tempat kue kering}

Produk ini memilikidiameter $10 \mathrm{~cm}$ tinggi $15 \mathrm{~cm}$, motif anyaman yang digunakan pada produk ini yaitu motif anyaman sasag dengan balutan warna asli dari bambu.

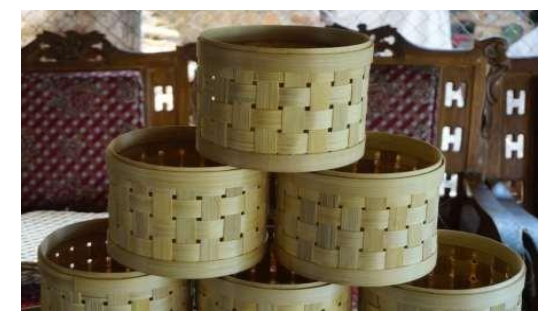

Gambar 5. Tempat kue kering

Sumber : Dokumentasi pribadi

\section{6) Kotak makanan}

Motif anyaman yang diganakan pada produk ini yaitu motif anyaman sasag, tutupnya menggunakan bingkai dari bambu tanpa di anyam. Warna yang digunakan pada kotak makanan ini merupakan warna asli dari bambu, nilai alami pada produk ini sangat terlihat jelas. 


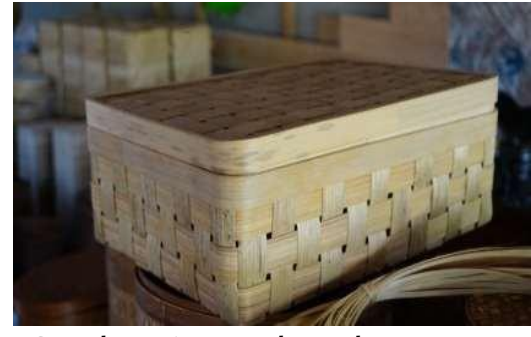

Gambar 6. Kotak makanan

Sumber : Dokumentasi pribadi

\section{Analisis motif}

Berbagai motif yang diciptakan dalam sebuah karya anyaman merupakan bentuk visual yang mempunyai daya tarik tersendiri. Anyaman bambu di Desa Mandalagiri menggunakan motif dasar atau motif utama yaitu motif anyaman sasag dan anyaman kepang, adapun beberapa motif yang dibuat di anyaman bambu Desa Mandalagiri tapi jarang sekali diproduksi seperti motif tarawangan dan motif gerigi.

\section{a) Motif anyaman sasag}

Motif anyaman sasag adalah jenis motif anyaman yang secara visual bentuk motifnya khas kotak-kotak dan terkesan kokoh. Sasag menurut Purwadi dan Purnomo, merupakan bahasa sanekerta yang berarti sasak atau telur, sasak adalah nama suku di Indonesia. Adapun sebutan lain untuk motif anyaman sasag yaitu motif anyaman silang dan motif anyaman tunggal, disebut motif anyaman tunggal karena dalam proses pembuatannya menggunakan cara mengangkat satu dan menumpangkan satu iratan pakan pada iratan lungsin secara selang-seling, atau bisa juga sebaliknya angkat satu dan meumpangkan satu lungsin pada pakan. Proses demikian dapat dikenal dengan istilah "angkat satu-tumpang satu".

Motif anyaman sasag mempunyai pola jalinan yang menoton, namun jika dalam kreasi motif lain atau dengan cara mengatur jarak corak performanya tidak akan menoton lagi.

Pada motif anyaman sasag ini terdapat motif geometris dengan mamakai unsur garis persegi, motif geometris sudah dikenal dari zaman prasejarah dulu. Makna yang terkandung dalam motif sasag ini menggambarkan kehidupan sehari-hari yang dahulunya dibuat dengan memperhatikan kehidupan masyarakat dan terus berkembang mengikuti pekembangan zaman. Motif pada anyaman sasag ini dilakukan dengan pengulangan garis bidang yang beraturan dengan jarak yang sama.

Dalam konsep geometri, zaman dahulu orang belum mengenal motif geometri, mereka hanya membuat motif anyaman sasag berdasarkan dari alam yang menggambarkan kehidupan. Pada kajian geometrinya secara langsung bahwa pada motif geometri terlihat adanya bentuk yang mengarah pada matematika seperti persegi. Namun pada dasarnya semua motif tersebut awalnya diambil dan terinspirasi dari alam sekitar dan memiliki makna tersendiri sesuai dengan kehidupan nyata.

Upaya yang dilakukan agar motif ini tetap eksis di masyarakat yaitu dengan mengembangkan pola jalinan dengan tidak merubah nilai aslinya. Selain itu dalam penggunan motif anyaman sasag ini biasanya digunakan untuk membuat keranjang dan rantang, bahkan dapat dikombinasi dengan motif hias lainya.

Motif nyaman sasag tersebut jika dibuat rumus pola jalinannya adalah sebagai berikut. Prinsip motif anyaman sasag ialah, mengangkat satu lusi dan menumpangkan satu pakan. Menurut Bapa Oman (61) "motif anyaman sasag banyak digunakan dalam pembuatan keranjang".

\section{b) Motif anyaman kepang}

Motif anyaman kepang adalah jenis motif anyaman dengan teknik menganyam nya dua-dua. Selain itu nama lain nya adalah motif anyaman bilik, disebut dengan anyaman kepang karena pembuatanya sama dengan membuat kepangan rambut. Bahan-bahan akan 
dianyam dengan cara menyilang secara berurutan dan bersamaan, sama seperti teknik membuat motif anyaman sasag.

Motif anyaman kepang merupakan motif anyaman silang miring terbuat dari bambu yang tipis. Beberapa iratan lungsin disusun berderet dan berjajar ke kiri dan ke kanan. "Motif anyaman kepang dari segi tekniknya mempunyai banyak variasi yang masing-masing menghasilkan motif yang berbeda-beda" ( Garha, 2001:13).

Pada motif anyaman kepang juga terdapat motif geometris dengan memakai unsur persegi panjang, persegi panjang merupakan salah satu contoh dari bangunan datar pada pelajaran matematika.

Kita lihat persegi panjang ini memiliki empat buah sudut yang kesemuanya adalah sudut siku-siku sudut yang sama yaitu, ini bisa kita lihat dari tiap-tiap sudutnya yang lebih uniknya lagi persegi panjang adalah salah satu bangun datar yang sering kita temukan dimanamana dan hampir tidak terlepas dari persegi panjang, itu berarti persegi panjang sangat erat hubungannya dengan kehidupan .

Jika jenis anyam sasag mempunyai rumus jalinan angjat satu-tumpang satu (11), maka jenis anyam kepang mempunyai rumus jalinan angkat dua- tumpang dua (2-2). Berikut merupakan contoh gambar dari anyam motif kepang.

Anyaman kepang tersebut jika dibuat rumus pola jalinannya adalah sebagai berikut.

Bila dibanding dengan jenis motif anyam sasag, jenis motif kepang lebih mudah untuk dikembangkan dalam segi berkreasi motif. Satu hal yang harus diingat bahwa pada setiap kali selesai menjalinkan iratan harus selalu diakhiri dengan perapatan iratan. Dengan demikian lungsin atau pakan terisi penuh menjadi selembar ilab.

Motif anyaman kepang ini memberikan pelajaran yang sangat berarti dan bisa kita jadikan contoh serta gambaran dalam menjalani hidup ini, ini lebih dilihat dari motif kepang yang saling menyatu secara kuat, bisa dijadikan contoh dalam kehidupan ini bahwa apabila semua manusia bersatu maka akan menghasilkan bangsa yang besar dan maju karena bangsa ini tidak terlepas dari kerja sama.

\section{c) Teknik pembuatan motif anyaman bambu}

Menurut wawancara saya dengan Pak Oman tanggal 27 Juni 2021, pada dasarnya, menganyam atau membuat anyaman adalah menyusun lusin dan pakan. Lusin adalah bagian iratan yang disusun membujur sedangkan pakan adalah bagian iratan yang di susun melintang. Adapun motif utama anyaman yang digunakan di anyaman bambu Desa Mandalagiri yaitu motif anyaman sasag dan motif anyaman kepang.

Motif anyaman sasag adalah cara menganyam dengan mengangkat satu iratan lusin atau pakan dan menumpangkan satu iratan pakan atau lusin. Motif anyaman ini di Desa Mandalagiri dikenal dengan istilah anyaman angkat satu numpang satu.

Motif anyaman kepang adalah cara menganyam nya dengan mengangkat dua atau lebih iratan pakan/lusin dan menumpangkan dua atau lebih iratan lusin/pakan. Motif anyaman ini di Desa Mandalagiri dikenal dengan istilah anyaman angkat dua numpang 2 ( Wawancara dengan Bapa Oman 27 Juni 2021)

Menurut Bapa Oman (61) “ Teknik pembuatan anyaman tidak dilakukan menggunakan mesin bubut melainkan menggunakan tang manual ". Adapun penjelasan secara detail tentang teknik menganyam berupa motif sasag dan motif kepang adalah sebagai berikut : 


\section{d) Teknik membuat motif anyaman sasag}

Letakan dan susun beberapa lungsin secara berderet dan berjajar kekiri dan kekanan.

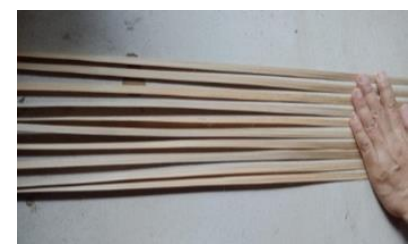

Gambar 7. Susunan lungsin

Sumber : Dokumentasi pribadi

Ambil iratan bambu sebagai pakan. Masukan iratan pakan tersebut diantara lusi yang dipegang tangan kiri.

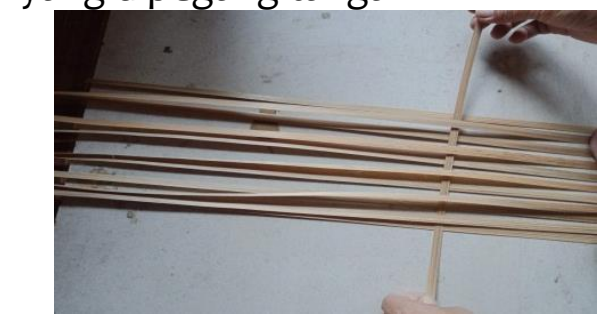

Gambar 8. Pemilihan celah lungsin

Sumber : Dokumentasi pribadi

Ambil iratan bambu sebagai pakan . Masukan iratan pakan ini diantara lusi yang dipegang tangan kiri . Ulangi pekerjaan serupa pada celah lusin nomor genap ( lusi keempat, keenam, dan seterusnya ) dari sisi kiri. Ambil iratan bambu sebagai pakan. Masukan iratan pakan tersebut diantara lusin yang dipegang tangan kiri. Setiap satu pakan telah disisipkan diantara lusin harus segera dirapatkan sehingga membentuk susunan anyaman yang rapat.

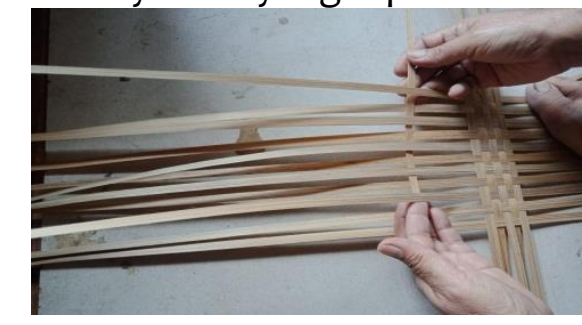

Gambar 9. Proses penganyaman

Sumber : Dokumentasi pribadi

Lakukan pekerjaan serupa secara bergantian sehingga sisipan pakan dan lusin tersebut membentuk lembaran anyaman utuh dan rapat (Wawancara dengan Bapa Oman 27 Juni 2021) Motif anyaman sasag ini biasa juga disebut anyaman angkat satu tindih satu atau $1 \times 1$.

\section{e) Teknik membuat motif anyaman} kepang

Prinsip membuat motif anyaman kepang mirip dengan anyaman sasag . Beberapa iratan lusin disusun berderet dan berjajar kekiri dan kekanan susunan lusi diatur rapi.

Angkat lusin pertama dan kedua kemudian angkat lunsin kelima, keenam, kesembilan, kesepuluh dan seterusnya, lalu pegang erat-erat dengan tangan kiri.

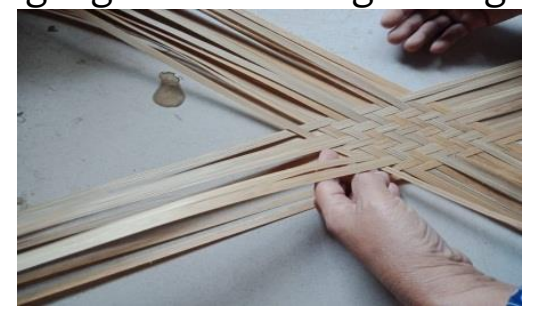

Gambar 9. Proses penganyaman

Sumber : Dokumentasi pribadi

Kemudian, sissipkan iratan pakan diantara lusin yang diangkat dan rapatkan sehingga membentuk lembaran anyaman kepang yang utuh dan rapat. (Wawancara dengan Ibu Yuyu 27 Juni 2021). Prinsip membuat motif anyaman ini biasa dikenal dengan prinsip anyaman angkat dua tindih dua.

\section{Kesimpulan Dan Saran}

Berdasarkan hasil analisis dari penelitian saya tentang motif kerajinan anyaman bambu di Desa Mandalagiri Kecamatan Leuwisari Kabupaten Tasikmalaya , ditinjau dari proses pembuatan, jenis produk yang dihasilkan dan motif, dapat disimpulkan sebagai berikut, Proses pembuatan meliputi :

Persiapan alat dan bahan

Alat-alat yang digunakan meliputi: gergaji, golok, pisau, palu, meteran, bor, lem dan amplas. Kemudian bahan anyaman bambu yang digunakan yaitu bambu tali atau bambu apus.

Motif anyaman bambu yang tedapat di Desa Mandalagiri sangat beragam 
tetapi hanya dua motif saja yang sering digunakan yaitu motif anyaman sasag dan motif anyaman kepang, dimana kedua motif tersebut dapat menghasilkan berbagai macam produk dengan bentuk yang berbeda-beda. Berdasarkan hasil analisis motif dapat disimpulkan bahwa motif sasag dan motif kepang ini terdapat motif geometris dengan memakai unsur garis persegi dan persegi panjang.

Teknik pembuatan motif anyaman tidak dilakukan menggunakan mesin bubut melainkan menggunakan tangan manual dengan alat dan bahan yang telah disediakan. Teknik membuat motif anyaman sasag yaitu dengan mengangkat satu lusi dan menumpangkan satu pakan, sedangkan pada motif anyaman kepang teknik pembuatannya yaitu dengan mengangkat lusi pertama dan kedua kemudian angkat lusi kelima, keenam, kesembilan, kesepuluh dan seterusnya, lalu dipegang erat dengan tangan kiri.

Melalui penelitian ini penulis mengajukan beberapa saran baik kepada beberapa pihak sebagai bahan pertimbangan dalam melakukan penelitian yang selanjutnya.

Dari hasil penelitian yang dilakukan mengenai kerajinan anyaman bambu di Desa Mandalagiri Kecamatan Leuwisari Kabupaten Tasikmalaya , terutama yang terkait dengan proses pembuatan, jenis jenis produk yang dihasilkan dan hasil analisis motif yang dilakukan sudah baik, namun ada beberapa hal yang sekiranya perlu diperhatikan lebih jauh dan dapat dijadikan pertimbangan bagi perkembangan produksi kerajinan anyaman bambu Desa Mandalagiri, yaitu:

1. Semoga para pengrajin tetap menjaga dan melestarikan ciri khas dan keaslian kerajinan anyaman bambu.

2. Semoga kerajinan anyaman bambu Desa Mandalagiri dapat mengembangkan produk-produk kerajinan anyaman bambu dengan motif dan motif hias yang beragam.

3. Perlu adanya dokumentasi dan arsip yang lengkap tentang motif dan produk-produk yang telah dihasilkan oleh pengrajin anyaman bambu Desa Mandalagiri.

4. Kepada pemerintah kabupaten Tasikmalaya kiranya dapat memberikan perhatian yang lebih, untuk ikut serta melestarikan dan mendukung potensi yang dimiliki oleh masyarakat Desa Mandalagiri.

5. Untuk lembaga pendidikan bisa menjadikan kajian lebih lanjut mengenai kerajinan daerah setempat yang ada di seluruh indonesia.

\section{Daftar Pustaka}

Caniago, Leri. M. 2019. Studi tentang produk Anyaman Bambu di Nagari Koto Baru Simalanggang Kecamatan Payakumbuh. Pendidikan Seni Rupa. Fakultas Bahasa dan Seni. Universitas Negeri Padang.

Daksopartono, I. 1983. Ilmu Menggambar : Balai Pustaka

Dharsono. 1951. Seni Rupa Modern : Rekayasa Sains

Garha, Oho. 1987. Berbagai Motif Anyaman. Bandung : Angkasa Bandung

Ilmiyah, Nur. Dkk. 2020. Analisis Motif Anyaman dan Aktivitas Fundamental Matematis Dalam Seni Menganyam di Desa Plaosan Kabupaten Kediri. Jurnal Pendidikan dan Pembelajaran Matematika, 2(1), 92-104.

K.Arifien, Koko. 2011. Peluang Bisnis Anyaman. Bandung : Yrama Widya 
Kurniawan, Adi F. 2015. Kerajinan Anyaman Bambu di Banjarwaru Nusawungu Cilacap Jawa

Tengah. Skripsi. Universitas Negeri Yogyakarta

Koentjaningrat (1974). Pengantar Antropologi, Jakarta: P.D Aksara

Mahzuni, Dede. Dkk. 2017. Pengembanga Kerajinan Tangan Berbasis Kearifan Budaya di Pekenjeng Kabupaten Garut. Jurnal Aplikasi Ipteks untuk Masyarakat, 6 (2), 101-105.

Murti, Hari.A.K. 2018. Kerajinan anyaman bambu di Sanggar Hamid Jaya Ds.Gintangan Kec.Rogojampi Kab.Banyuwangi. Jurnal Seni Rupa, 6 (1), 634-644.

Putri,Yeni. Dkk. 2014. Motif Hias Pada Kerajinan Anyaman Bambu di Kejapa Bamboo Handicraft, Ds.Tiga Waksa Kec.Banjar Kab.Buleleng. Jurnal Pendidikan Seni Rupa, 4(1), 1-10.

Raharjo, Timbul. 2011. Seni Kriya \& Kerajinan. Yogyakarta : Program Pasca Sarjana ISI Yogyakarta.

Ratnawati, Ike. 2015. Seni Kriya. Malang : Universitas Negeri Malang

Suciati,Rani, dan Anggun Badu Kusuma. 2019. Eksplorasi Etnomatematika pada Anyaman Bambu. Prosiding Sendika, 5 (1),252-259.

Sugiyono (2011), Metode Penelitian Kuantitatif Kualitatif dan R\&D Bandung:Alfabeta, cv.

Sunarto, Suherman. 2017. Apresiasi Seni Rupa: Thafa Media

Susilo, Singgih. dkk. 2019. Pendampingan Industri Lokal Anyama Bambu Untuk meningkatkan daya saing Pasar di Ds. Binaan Dusun.Kedampul Kec.Tumpang Kab.Malang. Jurnal praksis dan dedikasi sosial, 2 (1), 36-46.

Toekio M, Soegeng. 2000. Mengenal Ragam Hias Indonesia : Angkasa Bandung. 